\title{
A Brief Review on Neurologic and Psychiatric Manifestations of Celiac Disease
}

\author{
Vagner Ramirez Basilio, ${ }^{1,2}$, Rondón Garzón Nilson",3, Cuervo Casallas Martha1 \\ ${ }^{1}$ Multiple Sclerosis Program, Medicarte, Medellin, Colombia \\ ${ }^{2}$ Medical Institutions, Medellin, Colombia \\ ${ }^{3}$ Libre University, Bogota, Colombia \\ Email: Basilio_vagner@hotmail.com, Nilrondong@hotmail.com, Lilicu11@hotmail.com
}

Received 2 March 2016; accepted 8 May 2016; published 11 May 2016

Copyright (C) 2016 by authors and Scientific Research Publishing Inc.

This work is licensed under the Creative Commons Attribution International License (CC BY).

http://creativecommons.org/licenses/by/4.0/

(c) (i) Open Access

\begin{abstract}
Celiac Disease (CD) is a rare autoimmune disorder with manifestations at different levels including the central nervous system. The disease develops as a consequence of intolerance to gluten on individuals with genetic susceptibility. It originates as a result of the interaction between genetic and environmental factors, on individuals predisposed, through a faulty immune system response to prolamin derived peptides. Usually the diagnosis is established based on clinical suspicion, either within a suspicious family group context or in patients with suggestive manifestations of this disease.
\end{abstract}

Keywords

Celiac Disease, Diagnosis, Neurology, Psychiatry

\section{Introduction}

Celiac Disease (CD) is a rare autoimmune disorder with manifestations at different levels including the central nervous system. It is a disease that is developed as a consequence of intolerance to gluten on individuals with genetic susceptibility.

Celiac disease is a permanent intolerance to gluten proteins from wheat (gliadin), barley (hordein), rye (secalin), representing $80 \%$ of wheat proteins.

Gluten contains hundreds of proteins with high prolamin content (proline glutamine), and low aminoacids concentration [1]. 
CD is characterized by acute and chronic mucous and submucous inflammation of the small intestine producing a malabsorption syndrome and symptoms, by which it is deemed an enteropathy from malnutrition but with different systemic expressions, some caused by this entity and other associated to this pathology [2]-[5].

CD prevalence varies from $0.6 \%$ to $5.6 \%$ of the general population; this differs in values according to geographical location, 1\% in Europe and in the United States [6] [7] up to 5.6\% in Africa [8] [9]. It is 1.5 to 2 times more frequent in women than men. The population groups at highest risk for CD are those that have low levels of iron, osteopenia, diabetes mellitus Down and Turner's Syndromes [10]. And with familiars with first-degree relatives with CD, the CD was initially considered only in children but can be found in any age [11].

\section{Pathogenesis}

It originates on the interaction between genetic and environmental factors, on individuals with a predisposition through a faulty immune system response, to prolamin derived peptides.

The increase on intestine epithelial barrier permeability allows peptides to break through the mucous and react with submucous and lamina propria cells; triggering an inflammatory reaction mediated by TCD4+ lymphocytes as they come into contact with tissue transglutaminase (tTG) [12] modified gliadin. All this happens in the context of HLA-DQ2/DQ8 molecules [13].

The release of pro-inflammatory cytokines TNF $\alpha$, IL-12, IL-15, IL-18 [14] with no pro-proportional increase of $\alpha$ factor tumor necrosis, and growth transforming $\beta 1$ factor [15].

Among pro-inflammatory cytokines, IL-15 induces intraepithelial lymphocytes (SIL TCD8+) proliferation and activation which express NKG2D and CD94-NKG2A receptors, bound by MICA/B and HLA-E (stress molecules) [16].

All of this as a whole will affect matrix metalloproteinase (MMPs), responsible for extracellular matrix degradation [17] and mucous transformation.

\section{Genetic Factors}

HLA genes are among the best characterized in the development of the disease. HLA is thought to contribute to the development of celiac disease on 36 percent of siblings [18].

In most populations studies, patients express the HLA-DQ2 heterodimer encoded by the DQA $1 * 05$ and DQB1*02 alleles. The DQ2 is present in about 30\% of the general population [19]. HLA-DQ2 negative patients are usually positive (5\%) for the HLA-DQ8 encoded by the DQA1*03 and DQB1*0302 alleles [20] [21].

Another group of non-HLA genes can also intervene in CD development. Regions 5q 31-33 (CELIAC2) and 2q32 (CELIAC3) are some of the most characteristic.

The CELIAC2 region contains a group of cytokines encoding genes, which may intervene in regulating the immune system and the inflammation [22]. Multiple potentially functional genes variants IL4, IL5, IL9, IL13, IL17B all in the CELIAC2 locus, were typified in the Irish population, but none of variants showed association with the disease [23].

The CELIAC3 region located on the 2q33 chromosomal region contains CD28, CTL4 lymphocytic response regulating genes, controlling $\mathrm{T}$ cell response aspects. The union of CD28 with its ligands generates a positive signal for cytokines activation and proliferation [24].

Another gene involved is CELIAC4 located on the 19p 13.1 chromosomal region. This region contains over 140 genes, and some which are part of the immune response.

The best CELIAC4 region candidate is the MYO9B gene for myosin molecule involved in the remodeling of enterocytes [25] [26].

In relation to other elements involved in the development of Celiac Disease as infectious agents have adenovirus serotype 12, and rotavirus; other elements involved are the quality of ingested gluten, the amount of ingested gluten, pregnancy, emotional stress, menopause, gastrointestinal infections antibiotic use, and drug as isotretinoin.

\section{Diagnosis}

The diagnosis of celiac disease is established based on clinical history, serologic studies, and intestinal biopsy. It is important to Differential diagnosis of other diseases such as immunological infectious diseases, autoimmune neoplastic among others (Table 1). 
Table 1. Differential diagnoses.
- Autoimmune enteropathy
- HIV enteropathy
- Common immunedeficiency variable
- Eosinophilic enteritis
- Vasculitis
- Intestinal lymphoma
- Mastocytosis
- Hypogammaglobulinemia
- Chronic small intestine ischemia
- Tropical sprue
- Amyloidosis
- Whipple Disease
- Parasitosis
- Helicobacter pylori infection
- Bacterial overgrowth
- Tuberculosis
- Zolliger-Ellison Syndrome
- Crohn's Disease

\section{Diagnosis Test}

General diagnosis includes a series of serological, genetic response tests to gluten-free diet, and intestinal biopsy when serologic tests are not sufficient.

Among serologic tests we have anti-gliadin antibodies (AGA), seldom requested on account of their low sensitivity and specificity [27], antiendomysial antibodies (EMA) [28], (which are requested along with total immunoglobulin A (IgA) serum level, due to frequent deficit in CD patients), and tissue antitransglutaminase (tTGA) [29], both with a high sensitivity and specificity.

Peptide gliadindetermination is a new technique for IgA deficient patients [30] [31].

$\mathrm{CD}$ is closely linked to the HLA region; the highest titles are set for the HLADQ2, while the remaining titles are for the DQ8 (Figure 1).

It has been suggested that these markers not only indicate genetic susceptibility, also are useful in diagnosing patients when it is not clear after intestinal biopsy [32] [33].

Only in some cases, diagnosis is established by duodenum biopsies; as a result of histological injuries just as the physiopathological characteristics in 1992 Marsh designed a system to classify morphological changes secondary to gluten enteropathy; this was modified by Oberhauer, in 1999. This system integrated physiopathology with histological alterations [34] (Table 2).

\section{Clinical Manifestations}

Time has provided several concepts on CD forms of presentation (typical, atypical, potential silent and latent CD, among others). Based on the heterogeneity of these terms, in 2013, Oslo experts published the results consensus which homogenized $C D$ related definitions. The consensus accepts the terms:

Asymptomatic CD defined by the absence of clinical manifestations: defined by the absence of clinical manifestations in spite of the existence of a lesion; it is diagnosed by serological studies and biopsy on populations potentially positive for CD development (equivalent to the silent CD concept).

Classic CD is characterized by symptoms of malabsorption, diarrhea, steatorrhea, weight loss, lack of growth and hypoalbuminemia.

Non-classic CD refers to CD patients without malabsorption signs or symptoms. Mono-symptomatic disease patients (expecting diarrhea or steatorrhea may fall in this classification). 


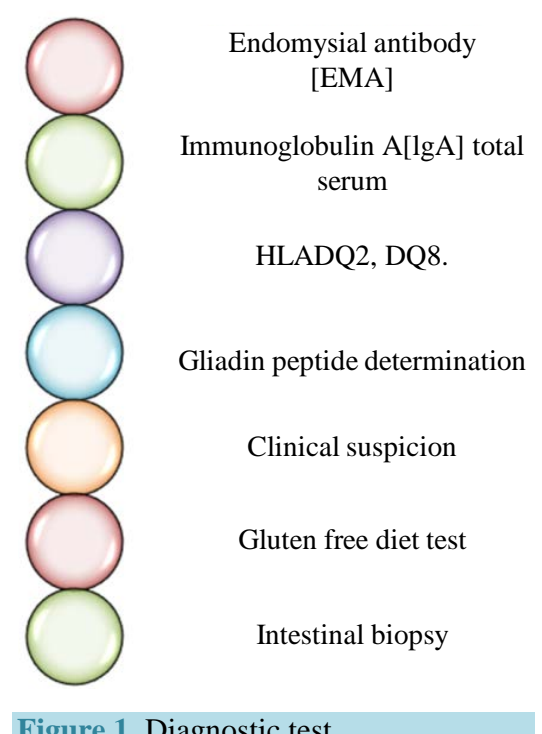

Figure 1. Diagnostic test.

Table 2. Classification marsh, Oberhuber.

\begin{tabular}{cccc}
\hline Classification & Lymphocytes & Hyperplasia & Atrophy \\
\hline $\mathbf{0}$ & $<30 / 100$ & - & Pre-infiltrative \\
$\mathbf{1}$ & $>30 / 100$ & - & Infiltrative \\
$\mathbf{2}$ & $>30 / 100$ & + & Infiltrative Hyperplasia \\
3A & $>30 / 100$ & + & Partial flattening \\
3b & $>30 / 100$ & + & Subtotal \\
3c & $>30 / 100$ & + & Total \\
$\mathbf{4}$ & $<30 / 100$ & - & Total [hypoplasicatrophy] \\
\hline
\end{tabular}

Subclinical $C D$ found below the clinical detection threshold, refers to CD patients with extra-intestinal manifestations.

Potential CD includes patients with positive serology but with normal intestinal biopsy.

Symptomatic $C D$ is characterized by gastrointestinal symptoms and/or extra-intestinal symptoms caused forgluten ingestion [35].

\section{Associated Pathologies}

Different pathologies associated with CD are described in the same manner:

- Psoriasis.

- Squamous cell carcinoma.

- Osteoporosis.

- Systemic Lupus Erythematosus.

- Sjogren's syndrome.

- Non-Hodgkin Lymphoma.

- Autoimmune thyroiditis.

- Polymyositis.

- Primary biliary cirrhosis.

- Adisson disease.

- Alopecia areata.

- Small Intestine Adenocarcinoma. 


\section{Neurological Manifestations and Psychiatric Features}

\subsection{Neurological Manifestations}

Among neurological manifestations, it is important to differentiate between neurological symptoms associated to conditions or deficiency syndromes as it is the case with vitamin B1 deficiency, Wernicke-Korsak of syndrome [36], B6 seizures [37], B12 seizures [38], peripheral neuropathy, cognitive commitment, depression [39], vitamin E spinocerebellar ataxia, polyneuropathy and myopathy [40], riboflavin deficiency with motor neuronopathy [41].

\subsection{Epilepsy}

Epilepsy prevalence increase on celiac disease is unclear. When compared to the general population it is thought to be $1.2 \%$ to $5 \%$ higher.

Epilepsy associated to later brain calcifications has been described as a rare entity in celiac disease [42], (Figure 2) where the reduction of secondary folate levels due to poor absorption is considered the reason of such calcifications [43]; however on another theory silica toxicity seems to play an important role in the pathogenesis both on the calcifications and on the seizures [44].

The types of epilepsy in these patients can be focal or generalized, with significant variability on the electroencephalographic findings [45].

\subsection{Cephalea}

In celiac disease patients, migraines have been described on a series of cases and controls. In one study, migraines were present in 40 out of 188 celiac disease patients (21\%), when comparing with 13 out of 178 controls (7\%) [46].

On another pediatric population study, no differences were observed on the presence of celiac disease in 100 children with migraines and 1500 controls, considering $2 \%$ for both groups [47].

Another study performed on the adult population showed that out of 90 migraines patients, 4 had celiac disease [4.4\%], in comparison 1 out of 236 controls [0.4\%] [48].

Currently there are some discrepancies over the real prevalence of this entity on the migraines, and over the most appropriate therapeutic plan. In a study conducted on the pediatric population, 16 patients ( 9 with migraines, 6 with non-specific cephalea) [49], the symptoms were resolved or improved significantly with a gluten-free diet.



Figure 2. CT scan of patient admitted for outpatient service by epilepsy with gastrointestinal symptoms in the course of celiac disease. 
In the same manner, the presence of cephalea and brain imagining alterations have been described on gluten sensitive patients [50].

\subsection{Myopathy}

The association between myopathy and CD is rare; at present we only isolated cases have been reported [51] [52]. A report on 13 patients with symptoms and signs of myopathy, 3 of those patients had neuropathybesides the myopathy, with or without ataxia; 10 patients had neurophysiologic evidence of myopathy. 1 patient had lesions suggesting myositis by inclusion bodies. These 6 patients were treated with immunosuppressive medication, besides gluten free-diet, 5 improved and 1 remained unchanged. Among the 7 patients who were not on immunosuppressive therapy, 4 showed improvements from the myopathy with a gluten-free diet [53].

\subsection{Cerebellar Ataxia}

Ataxia is the most frequent neurological manifestation; on the original description made by Cooke and Smith in 1966 [54], several patients had sensory ataxia however 3 of them had cerebellar ataxia. After this, numerous reports have been made on CD related ataxia [55]-[57].

Vitamin E deficiency has been considered one of the mechanisms responsible for this symptom, on account of relationship to patients with $\mathrm{CD}$, and the improvement in some cases after its reposition [58]; an immune mechanism has also been suggested in which AGAs are considered neurotoxic [59].

In CD related ataxia, antibodies against the Purkinje cells have been shown compromising the cerebellum deep cores.

In this phenomenon we can observe how gliadin proteins and Purkinje cells share common epitopes. Common epitopes were also shown between the giadin proteins and the enterocytes [60].

\subsection{Progressive Myoclonic Ataxia [Ramsay HUNT Syndrome]}

There are a number of reports where the association of progressive myocolinic ataxia and celiac disease is present [61]. Lu et al. reported 2 patients with Ramsay Hunt syndrome, in all there was a CD associated absorption disorder [62]. Tijssen et al. described 3 myoclonus patients; 2 had progressive ataxic syndrome and celiac disease; the 3 could have had CD with low B12 [63]. Bhatia KP et al. reported 4 patients with progressive myoclonic ataxia and CD; on them the symptoms persisted despite a gluten-free diet; plasmapheresis and immunesuppressive management were conducted on 2 patients with no improvement. Post-mortem examination on1 of these patients showed selective symmetric atrophy in the cerebellar hemispheres compromising the Purkinje cells, and preservation in the brain hemispheres and brain stem [64].

\subsection{Peripheral Neuropathy}

Celiac disease associated peripheral neuropathy has been reported in many cases [65] [66]; usually they are associated to distal sensitive symptoms, sensitivity loss and imbalance [67]; peripheral neuropathy can occur even before intestinal symptoms [68]. It can also be presented as ademyelinating and axonal polyneuropathy [69]; 50\% of CD patients develop peripheral neuropathy [70]. Thawani SP et al. presented a study that took place between October 27, 2006 and February 12, 2008, where data from small intestine biopsies was collected in different Swedish pathology departments; the risk of neuropathy was compared on 28.232 CD patients with 139,473 controls by age and sex. The results showed that celiac disease was associated to a risk 2.5 times greater than late neuropathy; also a greater risk of chronic demyelinating inflammatory neuropathy, autonomic neuropathy and mononeuritis was found, but there was no association between CD and acute inflammatory demyelinating polyneuropathy [71].

\subsection{Depression}

On CD patients, the depression producing mechanism is unclear. One possibility is a reduction in tryptophan concentration [72].

Alteration on the absorption of multiple nutrients [vitamins, amino acids] can produce a reduction in the concentration of various substances which will cause psychiatric manifestations. Morris et al. [73], as well as Hal- 
lert et al. [74] were the first to describe this association. Zingone et al. [75], and Siniscalchi et al. [76] showed depression was present on CD patients and that the symptoms persisted or worsened with a gluten-free diet.

Fera et al. [77] on an eight-year study on 100 treated patients, found a high rate of depression, which tended to improve in time, but that did not correlated with an adequate diet. Regional cerebral hypo-perfusion on CD patients, is also a condition which has been proposed as related to psychiatric conditions [78].

\subsection{Anxiety}

Anxiety in CD patients was described in a meta-analysis conducted by Smith et al. [79], where they analyzed eighteen studies on depression and eleven studies on anxiety on adulthood celiac disease, without encountering any significant difference regarding healthy adults or any other pathology.

Cannings-John et al., on a study of cases and controls found a greater number of consultations in the general practice during 5 years prior to $\mathrm{CD}$ diagnosis, with three clinical features associated independently: depression and/or anxiety [odds ratio [OR] $=2.5,95 \%$ confidence interval $[\mathrm{CI}]=1.1$ to $5.7 ; \mathrm{p}=0.031$ ]; diarrhea $[\mathrm{OR}=4.5$; $95 \%=2.0-10.0 ; \mathrm{p}<0.001$ ]; and anemia [OR = 26.3; CI 95\% = 5.7 to $\$ 120.6, \mathrm{p}<0.001$ ] [80].

Häuser et al. [81] conducted a study in 441 adult with CD, obtained by means of the German Celiac Society, where it was compared anxiety and depression levels in adult patients with celiac disease (CD) on a gluten-free diet (GFD) with controls. Finding anxiety in adult German female celiacs on a GFD is higher, than in persons of the German general population sample (GP).

In another study carried out by Esenyel S the levels of depression and anxiety of pediatric patients with CD and their parents do not differ from the healthy group [82].

\subsection{Schizophrenia}

CD associated schizophrenia is a psychiatric disorder described many years ago [83] [84].

In an article published in 1953, the incidence of CD was found to increase in childhood schizophrenia [85].

In a study performed by Dohan, the frequency admissions into psychiatric hospitals was surveyed during World War II in six countries undergoing wheat shortages, and the finding was a reduction in the frequency of schizophrenia related admissions [86].

A study similarly conducted observed a genetic association factor between these two entities related to the CLDN5 and DQB1 genes [87].

\subsection{Hyperactivity and Attention Deficit Disorder [ADHD]}

Pittschieler and Niederhofer evaluated a reduction of 132 CD participants from 3 to 57 years of age [M = 19.3 years] with the possibility of being ADHD-like, by using the Conner Hypescheme scale-before having a glutenfree diet and 6 months afterwards-being that non-treated ADHD-like patients with CD present an over-expression of symptoms and can significantly improve with a gluten-free diet [88].

However in various studies the manifestations of association are not conclusive [89] [90].

\section{Conclusions}

Currently, the commitment of the central nervous system associated to CD is poorly understood.

Although we have greater information on prevalence, pathogenesis, genetic factors and diagnostic tests, in some cases the physiopathological impairments responsible for neurological and psychiatric manifestations are just proposals.

Suspicion of subclinical CD is important; in some cases it is likely responsible for the etiology of multiple central nervous system pathologies. This must be taken into account especially on population groups where the prevalence is considered low.

\section{References}

[1] Bertolo, R.F. and Burrin, D.G. (2008) Comparative Aspects of Tissue Glutamine and Proline Metabolism. Journal of Nutrition, 138, 2032S-2039S.

[2] Rodrigo, L. (2006) Celiac Disease. World Journal of Gastroenterology, 7, 6585-6593.

http://dx.doi.org/10.3748/wjg.v12.i41.6585 
[3] Freeman, H.J. (2015) Iron Deficiency Anemia in Celiac Disease. World Journal of Gastroenterology, 21, $9233-9238$. http://dx.doi.org/10.3748/wjg.v21.i31.9233

[4] Anania, C., De Luca, E., De Castro, G., Chiesa, C. and Pacifico, L. (2015) Liver Involvement in Pediatric Celiac Disease. World Journal of Gastroenterology, 21, 5813-5822.

[5] Lauret, E. and Rodrigo, L. (2013) Celiac Disease and Autoimmune-Associated Conditions. BioMed Research International, 2013, Article ID: 127589. http://dx.doi.org/10.1155/2013/127589

[6] Mustalahti, K., Catassi, C., Reunanen, A., Fabiani, E., Heier, M., et al. (2010) The Prevalence of Celiac Disease in Europe: Results of a Centralized, International Mass Screening Project. Annals of Medicine, 42, 587-595. http://dx.doi.org/10.3109/07853890.2010.505931

[7] (2004) NIH Consensus Development Conference on Celiac Disease. NIH Consensus and State of the Science Statements, 21, 1-23.

[8] Catassi, C., Rätsch, I.M., Gandolfi, L., Pratesi, R., Fabiani, E., et al. (1999) Why Is Coeliac Disease Endemic in the People of the Sahara? Lancet, 21, 647-648. http://dx.doi.org/10.1016/S0140-6736(99)02609-4

[9] Catassi, C., Abu-Zakey, M., Kriszad, D. and Fasano, A. (2004) Celiac Disease among School-Children in Egypt: Results of a Pilot Study. 11th International Symposium on Celiac Disease, Belfast.

[10] Rubio-Tapia, A., Van Dyke, C.T., Lahr, B.D., Zinsmeister, A.R., El-Youssef, M., et al. (2008) Predictors of Family Risk for Celiac Disease: A Population-Based Study. Clinical Gastroenterology and Hepatology, 6, 983-987. http://dx.doi.org/10.1016/j.cgh.2008.04.008

[11] Rashtak, S. and Murray, J.A. (2009) Celiac Disease in the Elderly. Gastroenterology Clinics of North America, 38, 433-446. http://dx.doi.org/10.1016/j.gtc.2009.06.005

[12] Gotteland, M., Verbeke, S., Cruchet, S., Brunser, O., Ríos G., et al. (2003) [Tissue Anti-Transglutaminase Antibodies: A Better Test to Detect Minor Dietary Transgressions in Celiac Patients?]. Revista Médica de Chile, 131, 25-29.

[13] Megiorni, F., Mora, B., Bonamico, M., Barbato, M., Nenna, R., et al. (2009) HLA-DQ and Risk Gradient for Celiac Disease. Human Immunology, 70, 55-59.

[14] León, A.J., Garrote, J.A., Blanco-Quirós, A., Calvo, C., Fernández-Salazar, L., et al. (2006) Interleukin 18 Maintains a Long-Standing Inflammation in Coeliac Disease Patients. Clinical \& Experimental Immunology, 146, 479-485. http://dx.doi.org/10.1111/j.1365-2249.2006.03239.x

[15] Forsberg, G., Hernell, O., Melgar, S., Israelsson, A., Hammarström, S., et al. (2002) Paradoxical Coexpression of Proinflammatory and Down-Regulatory Cytokines in Intestinal T Cells in Childhood Celiac Disease. Gastroenterology, 123, 667-678. http://dx.doi.org/10.1053/gast.2002.35355

[16] Jabri, B., de Serre, N.P., Cellier, C., Evans, K., Gache, C., et al. (2000) Selective Expansion of Intraepithelial Lymphocytes Expressing the HLA-E-Specific Natural Killer Receptor CD94 in Celiac Disease. Gastroenterology, 118, 867-879. http://dx.doi.org/10.1016/S0016-5085(00)70173-9

[17] Daum, S., Bauer, U., Foss, H.D., Schuppan, D., Stein, H., et al. (1999) Increased Expression of mRNA for Matrix Metalloproteinases-1/-3 and Tissue Inhibitor of Metalloproteinase-1 in Intestinal Biopsy Specimens from Patients with Coeliac Disease. Gut, 44, 17-25. http://dx.doi.org/10.1136/gut.44.1.17

[18] Petronzelli, F., Bonamico, M., Ferrante, P., Grillo, R., Mora, B., et al. (1997) Genetic Contribution of the HLA Region to the Familial Clustering of Coeliac Disease. Annals of Human Genetics, 61, 307-317.

[19] Arranz, E. and Garrote, J.A. (2004) HLA en la enfermedad celíaca. Anales de Pediatría Continuada, 2, 163-166. http://dx.doi.org/10.1016/s1696-2818(04)71636-4

[20] Jabri, B. and Sollid, L.M. (2006) Mechanisms of Disease: Immunopathogenesis of Celiac Disease. Nature Reviews Gastroenterology and Hepatology, 3, 516-525. http://dx.doi.org/10.1038/ncpgasthep0582

[21] Rostom, A., Murray, J.A. and Kagnoff, M.F. (2006) American Gastroenterological Association [AGA] Institute Technical Review on the Diagnosis and Management of Celiac Disease. Gastroenterology, 131, 1981-2002. http://dx.doi.org/10.1053/j.gastro.2006.10.004

[22] Greco, L., Babron, M.C., Corazza, G.R., Percopo, S., Sica, R., Clot, F., et al. (2001) Existence of a Genetic Risk Factor on Chromosome 5q in Italian Coeliac Disease Families. Annals of Human Genetics, 65, 35-41. http://dx.doi.org/10.1046/j.1469-1809.2001.6510035.x

[23] Ryan, A.W., Thornton, J.M., Brophy, K., Daly, J.S., McLoughlin, R.M., O’Morain, C., et al. (2005) Chromosome 5q Candidate Genes in Coeliac Disease: Genetic Variation at IL4, IL5, IL9, IL13, IL17B and NR3C1. Tissue Antigens, 65, 150-155. http://dx.doi.org/10.1111/j.1399-0039.2005.00354.x

[24] Fasano, A. and Shea-Donohue, T. (2005) Mechanisms of Disease: The Role of Intestinal Barrier Function in the Pathogenesis of Gastrointestinal Autoimmune Diseases. Nature Reviews Gastroenterology and Hepatology, 9, 5-8. http://dx.doi.org/10.1038/ncpgasthep0259 
[25] Núñez, C., Márquez, A., Varadé, J., Martínez, A., Polanco, I., Maluenda, C., Fernández-Arquero, M., de la Concha, E.G. and Urcelay, E. (2006) No Evidence of Association of the MYO9B Polymorphisms with Celiac Disease in the Spanish Population. Tissue Antigens, 68, 489-492. http://dx.doi.org/10.1111/j.1399-0039.2006.00699.x

[26] Liao, N., Chen, M.-L., Zhao, H. and Xie, Z.-F. (2015) Association between the MYO9B Polymorphisms and Celiac Disease Risk: A Meta-Analysis. International Journal of Clinical and Experimental Medicine, 8, 14916-14925.

[27] Troncone, R. and Ferguson, A. (1991) Anti-Gliadin Antibodies. Journal of Pediatric Gastroenterology \& Nutrition, 12, 150-158. http://dx.doi.org/10.1097/00005176-199102000-00002

[28] Salmi, T.T., Collin, P., Korponay-Szabó, I.R., Laurila, K., Partanen, J., Huhtala, H., Király, R., Lorand, L., Reunala, T., Mäki, M., et al. (2006) Endomysial Antibody-Negative Coeliac Disease: Clinical Characteristics and Intestinal Autoantibody Deposits. Gut, 55, 1746-1753. http://dx.doi.org/10.1136/gut.2005.071514

[29] Lewis, N.R. and Scott, B.B. (2010) Meta-Analysis: Deamidatedgliadin Peptide Antibody and Tissue Transglutaminase Antibody Compared as Screening Tests for Coeliac Disease. Alimentary Pharmacology \& Therapeutics, 31, 73-81. http://dx.doi.org/10.1111/j.1365-2036.2009.04110.x

[30] Mozo, L., Gómez, J., Escanlar, E., Bousoño, C. and Gutiérrez, C. (2012) Diagnostic Value of Anti-Deamidated Gliadin Peptide IgG Antibodies for Celiac Disease in Children and IgA-Deficient Patients. Journal of Pediatric Gastroenterology and Nutrition, 55, 50-55. http://dx.doi.org/10.1097/MPG.0b013e31824703c7

[31] Leffler, D.A. and Schuppan, D. (2010) Update on Serologic Testing in Celiac Disease. The American Journal of Gastroenterology, 105, 2520-2524. http://dx.doi.org/10.1038/ajg.2010.276

[32] Chang, M. and Green, P.H. (2009) Genetic Testing before Serologic Screening in Relatives of Patients with Celiac Disease as a Cost Containment Method. Journal of Clinical Gastroenterology, 43, 43-50. http://dx.doi.org/10.1097/MCG.0b013e318187311d

[33] Husby, S., Koletzko, S., Korponay-Szabo, I.R., Mearin, M.L., Phillips, A., Shamir, R., Troncone, R., Giersiepen, K., Branski, D., Catassi, C., et al. (2012) European Society for Pediatric Gastroenterology, Hepatology, and Nutrition Guidelines for the Diagnosis of Coeliac Disease. Journal of Pediatric Gastroenterology \& Nutrition, 54, 136-160. http://dx.doi.org/10.1097/MPG.0b013e31821a23d0

[34] Oberhuber, G., Granditsch, G. and Vogelsang, H. (1999) The Histopathology of Coeliac Disease: Time for a Standardized Report Scheme for Pathologists. European Journal of Gastroenterology \& Hepatology, 11, 1185-1194. http://dx.doi.org/10.1097/00042737-199910000-00019

[35] Ludvigsson, J., Leffler, D., Bai, C., et al. (2013) The Oslo Definitions for Coeilic Disease and Related Terms. Gut, 62, 43-52. http://dx.doi.org/10.1136/gutjnl-2011-301346

[36] Butterworth, R.F., Kril, J.J. and Harper, C.G. (1993) Thiamine-Dependent Enzyme Changes in the Brains of Alcoholics: Relationship to the Wernicke-Korsakoff Syndrome. Alcoholism: Clinical and Experimental Research, 17, 10841088. http://dx.doi.org/10.1111/j.1530-0277.1993.tb05668.x

[37] Santana Cabrera, L., Amela, R., Rodríguez González, F. and Sánchez-Palacios, M. (2007) [Status Epilepticus Due to Low Vitamin B6 Levels Refractory to Convencional Antiepileptic Treatment during Pregnancy]. Medicina Clinica, 129, 239. (In Spanish) http://dx.doi.org/10.1157/13107933

[38] Yavuz, H (2008) Vitamin B12 Deficiency and Seizures. Developmental Medicine \& Child Neurology, 50, 720. http://dx.doi.org/10.1111/j.1469-8749.2008.03083.x

[39] Oh, R. and Brown, D.L. (2003) Vitamin B12 Deficiency. American Family Physician, 67, 979-986.

[40] Brigelius-Flohé, R. and Traber, M.G. (1999) Vitamin E: Function and Metabolism. The FASEB Journal, 13, 11451155.

[41] Manole, A. and Houlden, H. (2015) Riboflavin Transporter Deficiency Neuronopathy. In: Pagon, R.A., Adam, M.P., Ardinger, H.H., Wallace, S.E., Amemiya, A., Bean, L.J.H., Bird, T.D., Fong, C.T., Mefford, H.C., Smith, R.J.H. and Stephens, K., Eds., GeneReviews ${ }^{\circledR}$ [Internet], University of Washington, Seattle, 1993-2015. http://www.ncbi.nlm.nih.gov/books/NBK299312

[42] Arroyo, H.A., De Rosa, S., Ruggieri, V., de Dávila, M.T. and Fejerman, N. (2002) Argentinean Epilepsy and Celiac Disease Group. Epilepsy, Occipital Calcifications, and Oligosymptomatic Celiac Disease in Childhood. Journal of Child Neurology, 17, 800-806. http://dx.doi.org/10.1177/08830738020170110801

[43] Bouquet, F., Ventura, A., Gobbi, G., Greco, L., Lambertini, A., Zaniboni, M.G. and Tassinari, C.A., Coordinators for the Italian Working Group on Coeliac Disease and Epilepsy (1992) Coeliac Disease, Epilepsy, and Cerebral Calcifications. The Lancet, 340, 439-443. http://dx.doi.org/10.1016/0140-6736(92)91766-2

[44] Toti, P., Balestri, P., Cano, M., Galluzzi, P., Megha, T., Farnetani, M.A., Palmeri, M.L., Vascotto, M., Venturi, C. and Fois, A. (1996) Celiac Disease with Cerebral Calcium and Silica Deposits: X-Ray Spectroscopic Findings, an Autopsy Study. Neurology, 46, 1088-1092. http://dx.doi.org/10.1212/WNL.46.4.1088 
[45] Magaudda, A., Dalla Bernardina, B., De Marco, P., Sfaello, Z., Longo, M., Colamaria, V., Daniele, O., Tortorella, G., Tata, M.A., Di Perri, R., et al. (1993) Bilateral Occipital Calcification, Epilepsy and Coeliac Disease: Clinical and Neuroimaging Features of a New Syndrome. Journal of Neurology, Neurosurgery \& Psychiatry, 56, 885-889. http://dx.doi.org/10.1136/jnnp.56.8.885

[46] Dimitrova, A.K., Ungaro, R.C., Lebwohl, B., Lewis, S.K., Tennyson, C.A., Green, M.W., Babyatsky, M.W. and Green, P.H. (2013) Prevalence of Migraine in Patients with Celiac Disease and Inflammatory Bowel Disease. Headache, 53, 344-355. http://dx.doi.org/10.1111/j.1526-4610.2012.02260.x

[47] Inaloo, S., Dehghani, S.M., Farzadi, F., Haghighat, M. and Imanieh, M.H. (2011) A Comparative Study of Celiac Disease in Children with Migraine Headache and a Normal Control Group. The Turkish Journal of Gastroenterology, 22, 32-35. http://dx.doi.org/10.4318/tjg.2011.0153

[48] Gabrielli, M., Cremonini, F., Fiore, G., Addolorato, G., Padalino, C., Candelli, M., De Leo, M.E., Santarelli, L., Giacovazzo, M., Gasbarrini, A., Pola, P. and Gasbarrini, A. (2003) Association between Migraine and Celiac Disease: Results from a Preliminary Case-Control and Therapeutic Study. The American Journal of Gastroenterology, 98, 625-629. Erratum in: (2003) The American Journal of Gastroenterology, 98, 1674. http://dx.doi.org/10.1111/j.1572-0241.2003.07300.x

[49] Zelnik, N., Pacht, A., Obeid, R. and Lerner, A. (2004) Range of Neurologic Disorders in Patients with Celiac Disease. Pediatrics, 113, 1672-1676.

[50] Hadjivassiliou, M., Grünewald, R.A., Lawden, M., Davies-Jones, G.A., Powell, T. and Smith, C.M. (2001) Headache and CNS White Matter Abnormalities Associated with Gluten Sensitivity. Neurology, 56, 385-388. http://dx.doi.org/10.1212/WNL.56.3.385

[51] Kozanoglu, E., Basaran, S. and Goncu, M.K. (2005) Proximal Myopathy as an Unusual Presenting Feature of Celiac Disease. Clinical Rheumatology, 24, 76-78. http://dx.doi.org/10.1007/s10067-004-0977-5

[52] Uthar, R., Sankhyan, N., Thapa, B.R. and Singhi, P. (2013) Proximal Myopathy: A Rare Presentation of Celiac Disease. Journal of Child Neurology, 28, 1485-1488. http://dx.doi.org/10.1177/0883073813497513

[53] Hadjivassiliou, M., Chattopadhyay, A.K., Grünewald, R.A., Jarratt, J.A., Kandler, R.H., Rao, D.G., Sanders, D.S., Wharton, S.B. and Davies-Jones, G.A. (2007) Myopathy Associated with Gluten Sensitivity. Muscle \& Nerve, 35, 443450. http://dx.doi.org/10.1002/mus.20709

[54] Cooke, W.T. and Smith, W.T. (1966) Neurological Disorders Associated with Adult Coeliac Disease. Brain, 89, 683722. http://dx.doi.org/10.1093/brain/89.4.683

[55] Ghezi, A., Filippi, M., Falini, A. and Zaffaroni, M. (1997) Cerebral Involvement in Celiac Disease: A Serial MRI Study in a Patient with Brainstem and Cerebellar Symptoms. Neurology, 49, 1447-1450. http://dx.doi.org/10.1212/WNL.49.5.1447

[56] Hadjivassiliou, M., Gibson, A., Grünewald, R., Davies-Jones, G.A.B., Chattopadhyay, A., Kandler, R., Kandler, R. and Jarratt, J. (1997) Idiopathic Ataxia of Late Onset: Gluten Sensitivity Is Part of the Answer. Journal of Neurology, Neurosurgery and Psychiatry, 63, 267.

[57] Hadjivassiliou, M., Rao, D.G., Grìnewald, R.A., Aeschlimann, D.P., Sarrigiannis, P.G., Hoggard, N., Aeschlimann, P., Mooney, P.D. and Sanders, D.S. (2016) Neurological Dysfunction in Coeliac Disease and Non-Coeliac Gluten Sensitivity. American Journal of Gastroenterology, 111, 561-567. http://dx.doi.org/10.1038/ajg.2015.434

[58] Mauro, A., Orsi, L., Mortara, P., Costa, P. and Schiffer, D. (1991) Cerebellar Syndrome in Adult Celiac Disease with Vitamin E Deficiency. Acta Neurologica Scandinavica, 84, 167-170. http://dx.doi.org/10.1111/j.1600-0404.1991.tb04927.x

[59] Collin, P., Pirttila, T., Nurmikko, T., et al. (1991) Celiac Disease, Brain Atrophy, and Dementia. Neurology, 41, 372375. http://dx.doi.org/10.1212/WNL.41.3.372

[60] Krupickova, S., Tuckova, L., Flegelova, Z., Michalak, M., Walters, J.R., Whelan, A., et al. (1999) Identification of Common Epitopes on Gliadin, Enterocytes, and Calreticulin Recognised by Antigliadin Antibodies of Patients with Coeliac Disease. Gut, 44, 168-173. http://dx.doi.org/10.1136/gut.44.2.168

[61] Tunc, T., Okuyucu, E., Ucleri, S., Sonmez, T., Coskun, O., Selvi, E. and Inan, L.E. (2004) Subclinical Celiac Disease with Cerebellar Ataxia. Acta Neurologica Belgica, 104, 84-86.

[62] Lu, C.-S., Thompson, P.D., Quinn, N.P., Parkes, J.D. and Marsden, C.D. (1986) Ramsay Hunt Syndrome and Coeliac Disease: A New Association? Movement Disorders, 1, 209-219. http://dx.doi.org/10.1002/mds.870010306

[63] Tijssen, M.A.J., Thom, M., Ellison, D.W., Wilkins, P., Barnes, D., Thompson, P.D. and Brown, P. (2000) Cortical Myoclonus and Cerebellar Pathology. Neurology, 54, 1350-1356. http://dx.doi.org/10.1212/WNL.54.6.1350

[64] Bhatia, K.P., Brown, P., Gregory, R., Lennox, G.G., Manji, H., Thompson, P.G., Ellison, D.W. and Marsden, C.D. (1995) Progressive Myoclonic Ataxia Associated with Celiac Disease. The Myoclonus Is of Cortical Origin, but the Pathology Is in the Cerebellum. Brain, 118, 1087-1093. http://dx.doi.org/10.1093/brain/118.5.1087 
[65] Kaplan, J.G., Pack, D., Horoupian, D., DeSouza, T., Brin, M. and Schaumburg, H. (1988) Distal Axonopathy Associated with Chronic Gluten Enteropathy: A Treatable Disorder. Neurology, 38, 642-645. http://dx.doi.org/10.1212/WNL.38.4.642

[66] Brannagan III, T.H., Hays, A.P., Chin, S.S., Sander, H.W., Chin, R.L., Magda, P., Green, P.H. and Latov, N. (2005) Small-Fiber Neuropathy/Neuronopathy Associated with Celiac Disease: Skin Biopsy Findings. JAMA Neurology, 62, 1574-1578. http://dx.doi.org/10.1001/archneur.62.10.1574

[67] Chin, R.L., Tseng, V.G., Green, P.H., Sander, H.W., Brannagan III, T.H. and Latov, N. (2006) Multifocal Axonal Polyneuropathy in Celiac Disease. Neurology, 66, 1923-1925. http://dx.doi.org/10.1212/01.wnl.0000208413.40583.6c

[68] Chin, R.L., Sander, H.W., Brannagan, T.H., Green, P.H., Hays, A.P., Alaedini, A. and Latov, N. (2003) Celiac Neuropathy. Neurology, 60, 1581-1585. http://dx.doi.org/10.1212/01.WNL.0000063307.84039.C7

[69] Boskovic, A. and Stankovic, I. (2014) Axonal and Demyelinating Polyneuropathy Associated with Celiac Disease. Indian Pediatrics, 51, 311-312.

[70] Cicarelli, G., Della Rocca, G., Amboni, M., et al. (2003) Clinical and Neurological Abnormalities in Adult Celiac Disease. Neurological Sciences, 24, 311-317. http://dx.doi.org/10.1007/s10072-003-0181-4

[71] Thawani, S.P., Brannagan III, T.H., Lebwohl, B., Green, P.H. and Ludvigsson, J.F. (2015) Risk of Neuropathy among 28232 Patients with Biopsy-Verified Celiac Disease. JAMA Neurology, 72, 806-811. http://dx.doi.org/10.1001/jamaneurol.2015.0475

[72] Hernanz, A. and Polanco, I. (1991) Plasma Precursor Amino Acids of Central Nervous System Monoamines in Children with Coeliac Disease. Gut, 32, 1478-1481. http://dx.doi.org/10.1136/gut.32.12.1478

[73] Morris, J.S., Ajdukiewicz, A.B. and Read, A.E. (1970) Neurological Disorders and Adult Coeliac Disease. Gut, 11, 549-554. http://dx.doi.org/10.1136/gut.11.7.549

[74] Hallert, C., Åstrøm, J. and Sedvall, G. (1982) Psychic Disturbances in Adult Coeliac Disease. Scandinavian Journal of Gastroenterology, 17, 25-28. http://dx.doi.org/10.3109/00365528209181039

[75] Zingone, F., Siniscalchi, M., Capone, P., Tortora, R., Andreozzi, P., Capone, E. and Ciacci, C. (2010) The Quality of Sleep in Patients with Coeliac Disease. Alimentary Pharmacology \& Therapeutics, 32, 1031-1036. http://dx.doi.org/10.1111/j.1365-2036.2010.04432.x

[76] Siniscalchi, M., Iovino, P., Tortora, R., et al. (2005) Fatigue in Adult Coeliac Disease. Alimentary Pharmacology \& Therapeutics, 22, 489-494. http://dx.doi.org/10.1111/j.1365-2036.2005.02619.x

[77] Fera, T., Cascio, B., Angelini, G., et al. (2003) Affective Disorders and Quality of Life in Adult Coeliac Disease Patients on a gluten-Free Diet. European Journal of Gastroenterology \& Hepatology, 15, 1287-1292. http://dx.doi.org/10.1097/00042737-200312000-00006

[78] Addolorato, G., Di Giuda, D., De Rossi, G., et al. (2004) Regional Cerebral Hypoperfusion in Patients with Celiac Disease. The American Journal of Medicine, 116, 312-317. http://dx.doi.org/10.1016/j.amjmed.2003.09.037

[79] Smith, D. and Gerdes, L. (2012) Meta-Analysis on Anxiety and Depression in Adult Celiac Disease. Acta Psychiatrica Scandinavica, 125, 183-193. http://dx.doi.org/10.1111/j.1600-0447.2011.01795.x

[80] Cannings-John, R., Butler, C.C., Prout, H., Owen, D., Williams, D., Hood, K., Crimmins, R. and Swift, G. (2007) A Case-Control Study of Presentations in General Practice before Diagnosis of Coeliac Disease. The British Journal of General Practice, 57, 636-642. Erratum in: (2007) The British Journal of General Practice, 57, 748.

[81] Häuser, W., Janke, K.H., Klump, B., Gregor, M. and Hinz, A. (2010) Anxiety and Depression in Adult Patients with Celiac Disease on a Gluten-Free Diet. World Journal of Gastroenterology, 16, 2780-2787. http://dx.doi.org/10.3748/wjg.v16.i22.2780

[82] Esenyel, S., Unal, F. and Vural, P. (2014) Depression and Anxiety in Child and Adolescents with Follow-Up Celiac Disease and in Their Families. The Turkish Journal of Gastroenterology, 25, 381-385.

[83] Kalaydjian, A.E., Eaton, W., Cascella, N. and Fasano, A. (2006) The Gluten Connection: The Association between Schizophrenia and Celiac Disease. Acta Psychiatrica Scandinavica, 113, 82-90. http://dx.doi.org/10.1111/j.1600-0447.2005.00687.x

[84] Eaton, W.W., Mortensen, P.B., Agerbo, E., Byrne, M., Mors, O. and Ewald, H. (2004) Coeliac Disease and Schizophrenia: Population Based Case Control Study with Linkage of Danish National Registers. BMJ, 328, 438. http://dx.doi.org/10.1136/bmj.328.7437.438

[85] Bender, L. (1953) Childhood Schizophrenia. The Psychiatric Quarterly, 27, 663-681. http://dx.doi.org/10.1007/BF01562517

[86] Dohan, F.C. (1946) Wartime Changes in Hospital Admissions for Schizophrenia. A Comparison of Admission for Schizophrenia and Other Psychoses in Six Countries during World War II. Acta Psychiatrica Scandinavica, 42, 1-23. http://dx.doi.org/10.1111/j.1600-0447.1966.tb01912.x 
[87] Wei, J. and Hemmings, G.P. (2005) Gene, Gut and Schizophrenia: The Meeting Point for the Gene-Environment Interaction in Developing Schizophrenia. Medical Hypotheses, 64, 547-552. http://dx.doi.org/10.1016/j.mehy.2004.08.011

[88] Niederhofer, H. and Pittschieler, K. (2006) A Preliminary Investigation of ADHD Symptoms in Persons with Celiac Disease. Journal of Attention Disorders, 10, 200-204. http://dx.doi.org/10.1177/1087054706292109

[89] Güngör, S., Celiloğlu, O.S., Ozcan, O.O., Raif, S.G. and Selimoğlu, M.A. (2013) Frequency of Celiac Disease in Attention-Deficit/Hyperactivity Disorder. Journal of Pediatric Gastroenterology \& Nutrition, 56, 211-214. http://dx.doi.org/10.1097/MPG.0b013e318272b7bc

[90] Abhimanyu, S. and Peter, H. (2015) Celiac Disease and Attention Deficit Hyperactivity Disorder: A Systematic Review of the Literature. Journal of Family Medicine \& Community Health, 2, 1069-1073.

\section{Abbreviations}

CD: celiac disease

AGA: anti-gliadin antibodies

EMA: antiendomysial antibodies

tTGA: tissue antitransglutaminase

GFD: gluten-free diet 